\title{
TEACHING ENGLISH TO ADULT STUDENTS AT MANAGEMENT RESEARCH AND EDUCATION (LP2M) EL-RAHMA EDUCATION CENTER PALEMBANG
}

\author{
Ariya Agustin \\ Politeknik Darussalam \\ ariyaagustin99@gmail.com
}

\begin{abstract}
The Objectives of the study are to describe the system used in Teaching English as a foreign language at LP2M El-Rahma Education Center Palembang, whether or not it is relevant with the principles of the procedure for the development of instructional system and to find out whether the system is suitable to the adult student's needs or not. A descriptive method was used in this research, becauase the writer described the data as they are. The subject of the study is the population of the second semester students of LP2M El-Rahma Education Center Palembang in the academic year 2006/2007, there are 180 students from the population 40 students are taken as the sample randomly. The data are obtained through documentation, interview to the English instructors who taught at LP2M El-Rahma Education Center Palembang . Observation and Questionaire given to the students. The data are analyzed by means of percentage. Based on the results of the data analysis, the writer found that the system used in TEFL at LP2M El- Rahma Education Center Palembang was relevannt to the system of teaching and the system applied was not suitable to the students' needs. they needed to learn English computer science in the term of writing grammatically, speaking with public either science textbooks espeacially which are written in English.
\end{abstract}

Keyword: Teaching English, adult students and LP2M.

\section{INTRODUCTION}

The objectives of teaching English in Indonesia have been documented legally and academically. Legally, the objective of TEFL is put in the decree of No/11/MPR?1993 issued by the people's congress which states that the objectives of teaching Englishas a foreign language at school is to utilize the language to broaden the student's reasoning horizons and to reinforce. Based on the statement above, The objective of Teaching English at Institute of management Research and Development ( LP2M) El-Rahma Education Center Palembang consist of two part: The aim of Elementary level: To give basic English knowledge the emphasizes on grammar, every day speaking, and reading comprehension and The aim of Intermediate level: To give the skills of speaking, 
and reading comprehension According to Fransisco citied in Davis ( 1990:5), the Objectives of current adult education are as follows:

1. Vocational efficiency

2. Economic Understating

3. Civic participation and responsibility

4. Better human relation and community improvement

5. Group Interest

6. Personal Growth and self-realization

Adults and Children are different. They have different areas of interst, ways of thinking, aims, and motivation.Something that interests the adults may not interst the children. The way to carry out the teaching or the techniques must also be different. Children as learners may not be valid for adults as learners ( J.Moon and Nikolov, 2000). The teaching of English is conducted with system. A short definition of the term is that it refers to any group interrelated components of parts which function together to achieve a goal (Amrin, $1984 ; 10$ ). Teaching as a system is an organized thigh, which comprises, integrated one another in order to achieve specific objective.

The teachers have to give materials and carry out the teaching in the way that is appropriate for the adults, when they teach adult students. To teach the adult students themselves, it can not be carried out by giving them the same materials or by using the same method, and the techniques. The teachers have considers their aims of taking an English course. Some of the Students, for example, want to be translators, othr want to be interpreters, etc. Something that is useful for translators to be may not useful for the interprenter bto be. In choosing the techniques to be to the Students, we also consider their abilities, aspiration and needs.

Method, the instructional procedure, used (Lang and Richards, 1987: 73) is one of important componets in educationand instruction. It means that the methods used by the teachers may influence the results of learning and determine the success or failure of the process of teaching and learning activities. The methodo;y of TEFL has five components ( Saleh, $1982: 14$ ). There are : 1. Instructional Objective, 2. Materials, 3. Teaching and Learning activities, 4. 
Resources, 5. Evaluation. Methodology or method has usually seemed to be most obviously central element within the main components of the total process. Whoever teaches, she or he precisely uses methods either consiously central within the main elements are objectives, material, media, and evaluation.

For the teaching material, at LP2M El- Rahma Education Center Palembang, students as well as the instructors use textbook call reading with understanding written by J.B Heaton-K Method and published in 1986 and practical English Grammar written by A.J Thomson and A.v Martinet and Published in 1980.Based on the background above, the writer takes the topic on " The teaching of English to the Adult Students at management Research and Development LP2M El- Rahma Education Center Palembang. This study focused on the answering of these questions. "What System is used in teaching of English to the Adult Students at management Research and Development LP2M ElRahma Education Center Palembang?". Is The system used by the instructors in teaching English Suitable to the students' needs?

\section{RESEARCH METHOD}

Descriptive method was applied in this study because the writer used to describes whether the system was suitable to the students' needs. As best and kahn ( 1993 :105) states : A descriptive study describes and interpreters what it is concern with the conditions or relationship that exist, opinions that are held, process, there are going on the facts there are evidence, or trends there are developing.it is primarily concerned with the present. Although it often to past events and influences as they relate to current, and accurately.

Population is a group of element or cases, whether individuals or events, that conform to specific criteria and to which we intented to generalize the result of the research ( MC Millan, 1992: 62 ). So, The writer took the second year students at LP2M El-Rahma Education Center palembvang as the population ofv the study. The total number of the population was 180 students from different classess. The first year students at LP2M El-Rahma Education Center palembang: 10 students of class computer of computer teacher traing class, 37 students of computer informatics technician class, 69 computer and bussiness administration 
class, and 12 students of computer and graphic design class, 34 students of business and accounting class, and 18 students computer and English class.

Sample is a small, portion of population selected for observation and Analysis ( Best, 1993: 13 ). The writer did not take all the second students of LP2M El-Rahma , But she only chosee $23 \%$ of the total number. It meant 40 students were observed. They were taken randomly by taking the small rolled papers, which had been mixed adn given names and numbers. In addition, the writer took all English instructors ( three Persons ) as the sample too.

The data Obtained by Using: Documentation, Interview, Observation and questionnaire are used.

\section{Documentation}

The data from documents were considered as main data. They were collected from syllabus and material ( textbooks) used at institute of management research and development el-rahma education center palembang

\section{Interview}

The interview was binteded to get additional data. The writer interwed the three instructors of english who taught the second semester students. The interviewed were aimed at getting the information about the components of teaching system

\section{Observation}

The data obtained from this technique were as additional information only, the observation was used in order to get more information on the actual teaching learning activities carried out by the instructors of english who taught the students, whether the data from the interviews were relevant with the reality or not

\section{Questionnaire}

The techinuque was used as additional data as those technique above. The writer distributed questionnaire to the sample students. The distribution of the questionnaire were aimed at getting the students' respone about TEFL at their institution, whether it was suitable to their needs or not. 
In doing this, the writer set some questions, which were in accordance with the problems to be solved. There are 21 items in multiple choice which each five option and 7 open ended questions. Those were almost always, usually, sometimes, seldom, almost never. The questions were given in bahasa indonesia in order to make it easier for the students to understand the meaning of each question

The information obtained is analyzed by systematic ways:

1. Classifying the data

2. Tabulating the data

3. Analyzing the data

4. making conclusion

The writer classifies the data into two groups :

1. The data from documents

2. The data from interview

3. The data from observation

4. The data from questionnaire

The data from documents were considered as main data. They were collected from syllabus and material and analyzed by to find out whether they respon the needs of the students to study effectively or not. The data obtained from interviews were analyzed by discarding the irrelevant data. The writer interviewed the instructors who taught in the first semester class and also the director of LP2M El- Rahma Education center Palembang. The quide sheet of interview was used in doing the interviews. The quide sheet of interview was given during the spare time outside the classrooms.

The data from observation were as supplementary data only. The writer did one month on teaching english at LP2M El- rahma Education Center Palembang in order to get more valid information on the actual teaching learning activity carried out by the instructors of english who taught the students, whether the data got from the interviews were relevant with reality. She entered class from 09:00 up to 10:30 am on Tuesday, from 07:30 up to 09:00 am on Wednesday and Thursday, 
and from 07:30 up to 09.00 am on Friday and Saturday and 07.30 up to 10.30 am on Monday.in doing the technique, she used a check list.

The data obtained from questionnaire was analyzed by discarding the irrelevant data. The distribution of the questionnaire was aimed at getting the students response about the TEFL at their institution, whether it was suitable to the students needs or not, data gained from the questionnaire was analyzed by using the formula of oercentage to calculate the results of the study and drew some conclusions.

\section{The Formula of Percentage:}

$$
P=\frac{F}{N} \quad x \quad 100 \%
$$

( Sudjiono, 1989: 40)

Which: $\quad \mathrm{P}=$ Percentage

$\mathrm{F}=$ the total of students choice

$\mathrm{N}=$ the number of students

\section{RESULTS OF THE RESEARCH}

\section{The Results from Documentation}

From the documentation as a source of materials used by the instructors and all second semester students of LP2M El- Rahma Education Center Palembang, the three categories ( content, skill, and function) listed in the syllabus were relevant with what written in that textbook.

Besides contents, skills and fuction, the students were also taught structures and grammar. From the syllabus the writer found that the instructional objectives of teaching english as a foreign language at LP2M El- Rahma education center was teaching english for general purpos and specific purpose as what the students of LP2M El- rahma Education Center Palembang needed Education. The syllabus contained of three categories. They were :

1. Contents

Simple introductions ; structural focus, contextual focus and informational focus. 
2. Skills

Language skill : listening information, guessing words from context. Speaking skill : speaking practice.

3. Function

The syllabus set language focus. They were : guesing unknown words, making application and business letters, working conditions, opening closing conversation, asking questions and responsibility, managing dicussion, reading for details, writing simple reports, using dictionary, defining, and identifiying

\section{The Results from the Interviews}

According to the Director of LP2M El- Rahma Education Center palembang, the general objective of teaching English at LP2M El- Rahma Education Center palembang was to make the students be able to have the four integreted skills in English ( Listening, speaking, writing, Reading ). Meanwhile, the specific objective were after graduating, the students are hoped to master English as an International language, English is used by most people all over the world besides be able to handle the common English sentences and how it used in computer science.

Besides the Director of El-Rahma Education center palembang, the writer also interviewed three instructors who taught in second semester classes during there spare time. In doing this, the writer set some questions for intervew containing the questionsin accirdance with the problem which were needed to be solved.

The writer found out the interviews that the instructors used eclectic methods by combining the advantageous principles and techniques of various methodologies in teaching and learning process with reasons not make the students bored and to make variations. However, they put more stress on comminicative approach and grammar translation because according to them it was appropriate with what stated in their syllabus.

She also found out that the instructors some supplementary materials from various sources. One of them used newspaper. In this opinions, the textbooks as 
well as the supplementary ones were more. They also like materials which had many pictures in the more than had no picture.

\section{The Results from the Observation}

The writer spent for one month to conducted observation in the class. This observation took one and half- hours. She entered class from 09:00 up to 10:30 am on Tuesday, from 07:30 up to 09:00 am on Wednesday and Thursday, and from 07:30 up to 09.00 am on Friday and Saturday and 07.30 up to 10.30 am on Monday.

It was found that the most of the five semester students were active enough in learning english. All of them were serious in paying attention and listening to the instructors' explanation. They also tried to participate actively in the following the lessons. However, tere were only a few students who were brave enough to speak in english since their abilities were still passive.

In doing this technique, the writer set a checklist that was given a tick, either in " yes " column " No " column. She set on the backseat of the students rows.

The writer found out that in their explanation, used quite english. The instructors read the material first or asked the students to read them., they explained what hadbeen read orally and also wrote things, which were necessary followed by the examples. The intructors used lecturing method, discussion method and row or three teaching techniqueall at one. However, they put more stress on communicative approach. They used mediasuch as newspaper. They did not use tape recorder, cassettes, cards, charts, games, language labory, overhead projector, television set, and another media.

In teaching and learning activities, the students' activities as well as the instructors were in balance. In the post stage, the intructors asked the students to write the outcomes of the lessons discessed at the moment in the form of exercises or homework. 


\section{The Results from the questionnaire}

From the questionnaire that the writer distributed to the 40 students as sample, the results obtained through this technique can be seen in table 2 below:

Table 1. The Results from questionnaire Institute of management Research Development LP2M El-Rahma Education center Palembang In Academic Year 2005-2006

\begin{tabular}{|c|c|c|c|c|c|c|c|c|c|c|}
\hline \multirow{2}{*}{ No } & \multicolumn{2}{|c|}{$\begin{array}{c}\text { Almost } \\
\text { Always }\end{array}$} & \multicolumn{2}{|l|}{ Usually } & \multicolumn{2}{l|}{ sometimes } & \multicolumn{2}{|c|}{ Seldom } & \multicolumn{2}{c|}{$\begin{array}{c}\text { Almost } \\
\text { Never }\end{array}$} \\
\cline { 2 - 12 } & NS & \% & NS & \% & NS & \% & NS & \% & NS & $\%$ \\
\hline 1 & 14 & 35 & 2 & 5 & 18 & 45 & 6 & 15 & - & - \\
\hline 2 & 12 & 30 & 10 & 25 & 13 & 32,5 & 4 & 10 & 4 & 10 \\
\hline 3 & 10 & 25 & 5 & 12,5 & 13 & 32,5 & 9 & 22,5 & 4 & 10 \\
\hline 4 & 20 & 50 & 10 & 25 & 6 & 15 & 2 & 5 & 2 & 5 \\
\hline 5 & 14 & 35 & 10 & 25 & 7 & 17,5 & 7 & 15,5 & 2 & 5 \\
\hline 6 & 11 & 27,5 & 9 & 22,5 & 17 & 42,5 & 2 & 5 & 2 & 5 \\
\hline 7 & 11 & 5 & 8 & 20 & 1 & 27,5 & 10 & 25 & 1 & 2,5 \\
\hline 8 & 2 & 5 & 7 & 15,5 & 12 & 30 & 12 & 30 & 5 & 12,5 \\
\hline 9 & 23 & 57,5 & 5 & 12,5 & 5 & 12,5 & 4 & 10 & 3 & 7,5 \\
\hline 10 & 17 & 42,5 & 6 & 15 & 10 & 25 & 5 & 12,5 & 2 & 5 \\
\hline 11 & 2 & 5 & 9 & 22,5 & 7 & 17,5 & 12 & 30 & 8 & 20 \\
\hline 12 & 9 & 22,5 & 12 & 30 & 13 & 32,5 & 2 & 5 & 4 & 10 \\
\hline 13 & 18 & 45 & 13 & 32,5 & 7 & 17,5 & 1 & 2,5 & 1 & 2,5 \\
\hline 14 & 1 & 2,5 & 2 & 5 & 10 & 25 & 4 & 10 & 23 & 57,5 \\
\hline 15 & 13 & 32,5 & 10 & 25 & 10 & 25 & 4 & 10 & 3 & 7,5 \\
\hline 16 & 3 & 7,5 & 5 & 12,5 & 11 & 27,5 & 10 & 25 & 11 & 27,5 \\
\hline 17 & 5 & 12,5 & 9 & 22,5 & 15 & 37,5 & 9 & 22,5 & 2 & 5 \\
\hline 18 & 11 & 27,5 & 11 & 27,5 & 14 & 35 & 4 & 10 & - & - \\
\hline 19 & 29 & 72,5 & 10 & 25 & 3 & 7,5 & - & - & - & - \\
\hline 20 & 11 & 27,5 & 9 & 22,5 & 8 & 20 & 7 & 17,5 & 4 & 10 \\
\hline 21 & 14 & 35 & 10 & 25 & 14 & 35 & 6 & 115 & 5 & 12,5 \\
\hline Avarege & $4,857.14$ & $4,659,52$ & $4,000,00$ & $3,809,52$ & $3,428,58$ \\
\hline & & & & & & & & & \\
\hline
\end{tabular}

Having know the results from the documents, the interviews, the observation, and the questionnaire, the writer found out the system used in teaching English as a foreign language at LP2M El-Rahma Education Center Palembang was relevant with the teaching system known as a procedure for the develpment of instructional system which consisted of five components. They were instructional objectives for general purpose, not spesific purpose, Reading with Understanding and a practical English Grammar, eclectic method was 
sometimes used, but more stress on communicative approach applied in teaching and learning process, and card, games, tape recorder were not used as media. Oral and written tests conducted to evaluated the students' achievement. However, the system applied was not suitable to adult students' needs.

\section{CONCLUSION AND SUGGESTIONS}

\section{a. Conclusion}

Based on the findings and analysis of the result of the questionnaire in the previous chapter some conclusion are drawn. Some conclusion in this study related with the problem and the thesis title "Teaching English to adults students at Institute of management Research and Development ( LP2M) El-Rahma Education Center. The System used by the instructors in teaching English at Institute of management Research and Development ( LP2M) El-Rahma Education Center was relevant with the system of teaching English know as Communicative approach.

\section{b. Suggestions}

Considering the findings and analysis of the result of the questionnaire this study, there are three suggestions were offered.

1. the system of teaching English should make specifically in the term of the instructional objectives made for specific purposes not general ones, the materials should be chosen discipline ( computer science )

2. To make the quality of English Teacher better, The Teacher should try to find or create the appropriate technique to be used.

3. For The Institution of management Research and Development ( LP2M) El-Rahma Education Center should have some supporting facilities as tave recorder, cassesttes,cards, games, televitions and another media.

\section{REFERENCES}

Allen, harold. 1972. Teaching English as a Second Language.

New York : MC Graw Hill, Inc

Blackie, david J. J.S 1987," service English for Students of Science and Technology."

English Teaching Forum, 119 (4):25

Brown, H. Doughlas. 1990 Principle of Language and Teaching.

Englewood Clift, new jersey : Prentice-hall, Inc 
Brown, James W and James W. Thorton, JR. 1963. College Teaching: A Systematic Approach, New York: McGraw-Hill, Inc

Harmer, Jerewy. 1983. The practice of English language Teaching. New York: Longman, Inc

Hubbard, Alfred W. 1973. Research Methods in Health, Psysica Education and Recreation, Washington D.C : AAHPER Publications

J.Moon \& M. Nikolov, M ( Eds) 2000 research into Teaching English to adults. International Perspective, Pecs : University press.

Lovell, Benard R. 1984. Adult Learning, London: Croom Helm

Rombepanjung, J.P. 1988. Pengajaran dan Pembelajaran Bahasa Asing: Sebuah Kumpulan Artikel. Jakarta: Depdikbud

Saleh, Yusrizal. 1982. Methods of Teaching as a Foreign Language: Fundamental of Language Teaching for Indonesia. Palembang: Sriwijaya University ..1990. Method of teaching English as a Foreign language. Palembang: Sriwijaya University

Saleh, Yusrizal. 1996. Methodology of TEFL in the Indonesia Context Book 1. Unpublished Book. Palembang : Sriwijaya University

Slavin. Robert E. 1992. Research Methods in Education. Boston, Massachusetts: A Division of Simonand Schuster, Inc

Sudjino, Anas. 1987. Pengantar Statistik pendidikan. Jakarta: Rajawali Press

Van, william Till. 1971. Education in Beginning. New York: Capital Record. 